\title{
Developing a legal assistant website "Notoaturan" using Waterfall method
}

\author{
Melinda Utami ${ }^{1)}$, Bita Parga Zen ${ }^{2)}$, Yayi Sufia Rauna ${ }^{3)}$ \\ 1)2)3) Telkom Institute of Technology Purwokerto \\ 1) $17102133 @$ ittelkom-pwt.ac.id, ${ }^{2)}$ bita@ittelkom-pwt.ac.id, ${ }^{3)}$ 17102120@ittelkom-pwt.ac.id
}

Submitted : Mar 3, 2021 | Accepted : Mar 21, 2021 | Published : Apr 1, 2021

\begin{abstract}
Currently, the development of information technology has had an influence on people's activities in their daily activities. Wherefrom the many activities that usually take a lot of time can be completed in a short time. This certainly occurs in all areas of life, one of which is in the field of law. The process of digitizing legal services can be realized if there is good support from the government, legal service providers, and the community. The problem of how to build a platform that can cover the entire legal service process without intervening in existing operational standards. The government itself has issued laws and regulations governing the digitization of legal services. Notoaturan is a websitebased platform created to support the legal service process that can be accessed online by the public. The development of the platform uses the waterfall method with the CodeIgniter 3 framework and the PHP programming language and the MySQL database. The results obtained are in the form of a notarized website that provides services related to notaries and lawyers. Notaries provide an orderly process for notary services such as creating a business entity, creating a CV, creating a PT, and others, as well as providing booking services for attorney services starting with prior consultation. The website is also equipped with several additional services such as complaints and assistance in using the website.
\end{abstract}

Keywords: CodeIgniter 3, Legal Assistance, MySQL, PHP, Website

\section{INTRODUCTION}

The Internet is one of the many advances in the development of science and technology that have succeeded in connecting millions of people around the world and allowing the rapid dissemination of information. The process of digitizing legal services at least plays an active role in the success of an advocate, notary, and lawyer. With the use of resources that run systematically, it can facilitate the implementation of duties and authority. As is well known, the existence of a notary is based on the need for evidence that is binding and as evidence that is the strongest and has essential juridical value in any legal relationship in the event of a dispute in public life.

Notaries also act as public officials and main duties and are empowered by the state to serve the public and public interest in making authentic evidence in the civil field in the form of Authentic Deeds. Apart from playing an active role in optimizing the performance of legal service actors, this platform can also help the general public in processing legal issues easily and effectively. Eliminate long procedures that usually occur in conventional or face-to-face service delivery processes to save required time and costs. Some service procedures that can be trimmed are, there is no longer a client waiting in line for the administrative process for hours because the administrative process can be carried out anytime and anywhere by the system or other examples, namely, there is no more submission of physical documents that are hundreds of sheets thick because supporting documents can be in the form of a pdf file that is uploaded into the system so that it saves more costs for printing documents.

This is the reason for the presence of the website-based Notoaturan platform as a product of Information and Communication Technology development that is feasible to be developed to help society and optimize the performance of legal service actors in providing public services. This website application will later be used as a medium that can bridge the community and legal service actors as well as a medium to provide legal services to anyone who needs it. The features presented in this platform include ordering assistance by lawyers, consulting in the field of law, making document services such as marriage certificates, creating business entities, and providing legal assistance to financially disadvantaged people.

This platform was developed using the waterfall method. The waterfall method is a method that emphasizes the development model to be done in a sequential and structured manner so that the implementation will be well documented and save costs. Unlike agile methods which tend to be more costly due to user feedback regarding changes or additions to software features. Also, the Waterfall method is suitable for large-scale software 
development that involves a lot of resources and complex work procedures. The development of this platform also uses the CodeIgniter 3 framework. Where CodeIgniter 3 is a PHP framework that applies the MVC concept so that it is easy to do maintenance. Also, this framework applies the OOP concept which makes it easier for developers to solve the problem, no need to write code repeatedly, and is easy to adapt.

\section{LITERATURE REVIEW}

Based on Law No. 16 of 2011 concerning Legal Aid, Article 1 (1) states that Legal Aid is legal services provided by Legal Aid Providers Free of Charge to Legal Aid Recipients. Legal aid recipients are people or groups of poor people who cannot fulfill their basic rights properly and independently who face legal problems. Whereas in SEMA No.10 of 2010 concerning Guidelines for Providing Legal Aid, it is stated that those who are entitled to services from the Legal Aid Post are people who are unable to pay for advocate services, especially women and children as well as persons with disabilities, following applicable law (UU RI 2011). The legal aid includes exercising the power of a lawyer, accompanying, representing, defending, and/or taking other legal actions for the legal interests of Legal Aid Recipients.

Current technological developments that have entered the realm of law have made their use even wider. One of them is the use of the internet. The internet is a global computer network formed from local and regional computer networks, enabling data communication between computers connected to the network (Tabrani Muhamad and Pudjiarti Eni 2017). One of the uses of internet technology is a website. A website can be interpreted as a collection a page that displays text data information, still, image or motion data, animation data, sound, video, and or a combination of all of them, be it static and dynamic that make up one a series of interconnected buildings were each linked by a network of pages (hyperlink) (Wijaya and Christian 2019).

One of the programming languages that are widely used to build websites in PHP. PHP started as a small opensource project that evolved as more and more people found out how useful it was. Rasmus Lerdorf unleashed the first version of PHP way back in 1994. PHP is a recursive acronym for "PHP: Hypertext Preprocessor". PHP is a server-side scripting language that is embedded in HTML. It is used to manage dynamic content, databases, session tracking, even build entire e-commerce sites. PHP is integrated with several popular databases, including MySQL, PostgreSQL, Oracle, Sybase, Informix, and Microsoft SQL Server (Ogala and Sylvester 2019).

In the development of website applications, there is a framework that is used as the basic structure of program code. A framework is a program structure that makes it easier for programmers to create an application so that it will be easier for programmers to make changes (customize) to the application and can reuse it for other similar applications. (Suharsana et al. 2016).

CodeIgniter is one type of framework for developing web-based applications. CodeIgniter is an open-source framework that makes it easier for users to create a dynamic PHP programming language. The advantage and purpose of developing applications using CodeIgniter are to help developers create applications faster than writing all source code from scratch and CodeIgniter provides many types of libraries that can make it easier to build and develop. CodeIgniter was launched to the general public on February 28, 2006. CodeIgniter was built and developed using the Model-View-Controller (MVC) concept (Endra, Cucus, and S 2020). Model-View-Controller (MVC) is a concept introduced by the inventor of Smalltalk (Trygve Reenskaug) to encapsulate data along with processing (model), isolating from the manipulation process (controller) and views to be represented on a user interface (Sudradjat 2019).

A database is a collection of data that is systematically stored on a computer and can be processed or manipulated using software (application programs) to produce information. Database definitions include specifications in the form of data types, structures, and data limitations to be stored (Tristianto 2018). MySQL is a popular open-source SQL database management system that is developed, distributed, and supported by Oracle Corporation. MySQL manages a structured collection of data. A MySQL database helps you to add, access, and process the data stored in the database. MySQL stores data in separate tables. The database structures are organized into physical files optimized for speed. The logical model, with objects such as databases, tables, views, rows, and columns, offers a flexible programming environment. The SQL part of "MySQL" stands for "Structured Query Language," which is the most common standardized language used to access databases. MySQL software uses the GPL (GNU General Public) License and is opensource software (Christudas Binildas 2019).

The waterfall model developed by B. W. Boehm is a sequential design process and is used in traditional software developments. This model shows the progress flowing downwards steadily exactly like a waterfall through all the phases like conception, initiation, analysis, design, construction, testing, production/implementation, and maintenance. This concept of this model originates from the construction and manufacturing industry. This model shows highly structured physical environments in which there is no possibility of improvement. Since no formal software development methodologies existed in past and this hardware-oriented model was simply adapted for software development (Manhas 2017).

The Waterfall method is a sequential software development process, in which progress is seen as continuously flowing downward (like a waterfall) through the phases of planning, modeling, implementation (construction), and 
testing. In its development, the waterfall method has several coherent stages: requirements (needs analysis), system design (system design), Coding \& Testing, Program Implementation, maintenance (Tristianto 2018).

Testing methods (or strategies) define the way for designing test cases. They can be responsibility-based (black-box), implementation-based (white box), or nonfunctional. Black-box techniques design test cases based on the specified functionality of the item to be tested (Boni Garcia 2017). black-box testing is a testing technique that focuses on the functional specifications of the software. Testing works by ignoring the structure of the control so it focuses on domain information. Testing using black-box testing allows system developers to create a set of input conditions that will exercise all functional limitations on a system (Ma'ruf, Kartiko, and Citra 2020).

\section{METHOD}

the stage of making a website is done using the Waterfall Software Development method. The Waterfall Software Development method consists of 5 stages, it is Requirement Analysis, System Design, Implementation, Testing, deployment, and Maintenance (Putra 2020).

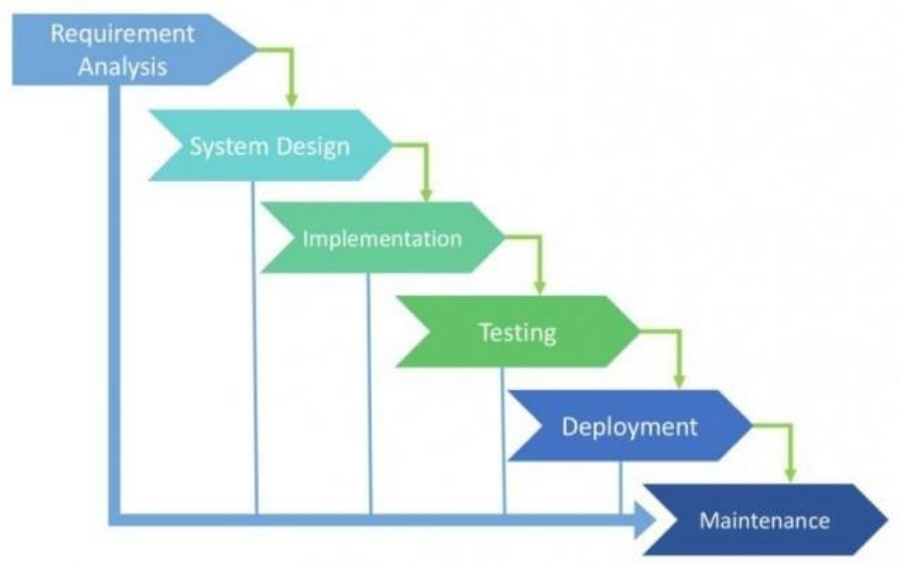

\section{Requirement}

Fig 1. Waterfall Software Development Models (Putra 2020).

This is the stage where the developer prepares and analyzes the software requirements to be created. Exploration of needs is carried out through observation and interviews, while the results obtained are as follows:

Table 1

Requirement Stage

\begin{tabular}{ll}
\hline \multicolumn{1}{c}{ Stage } & \multicolumn{1}{c}{ Requirement } \\
\hline Observation & Make observations of several existing legal \\
websites to obtain sufficient information that can \\
be used for development. \\
In this case the interview was conducted to one of \\
the notaries with the following questions: \\
What legal services are there? \\
What is the SOP for legal services if it is \\
conducted digitally, is it flexible or creates new \\
problems? \\
What is the legality of documents if legal \\
services are carried out digitally? \\
Can this new system make it easier to collect \\
documents as a service requirement?
\end{tabular}

\section{Design}

Design Sprint

Sprint design aims to design a business plan, website prototype, and user test analysis which will later be used as a reference in the website creation process. The sprint design is carried out for 5 days (from Monday to Friday) with details of the activities that include (Knapp Jake, Zeratsky John 2016). 
Table 2

Desain Sprint

\begin{tabular}{ll}
\hline \multicolumn{1}{c}{ Day } & \multicolumn{1}{c}{ Activities } \\
\hline & Setting long-term goals \\
& Make a sprint map design \\
Day 1: Monday & Make a sprint question \\
& Discussion and evaluation \\
& Designing a solution sketch \\
& Lighting Demo \\
& Divide and swarm \\
& Designing with Crazy8 \\
& Discussion and evaluation \\
Day 2: Tuesday & Determine the best solution sketch \\
& Making Storyboard \\
& Discussion and evaluation \\
Day 3: Wednesday & Making Prototype \\
& Discussion and evaluation \\
Day 4: Thursday & prototype demo \\
& User testing \\
Day 5: Friday & Discussion and evaluation \\
\hline
\end{tabular}

\section{System \& Databases}

Use Case describes an interaction between one or more actors with the system to be created. In other words, use case diagrams are used to understand what functions are in a system and who can use them (Hendini 2016).

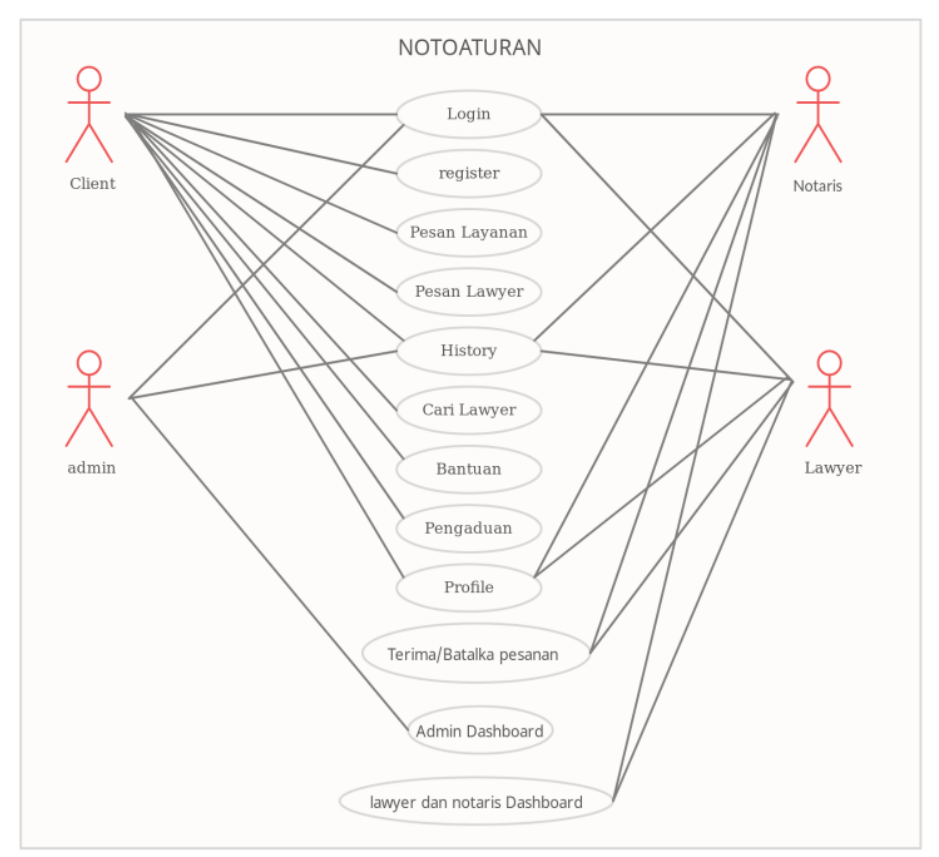

Fig 2. Usecase diagram

ER Diagram describes the data structure to explain the relationship between data in the database based on basic data objects that have relationships between relations (Eka Wida Fridayanthie 2016). 

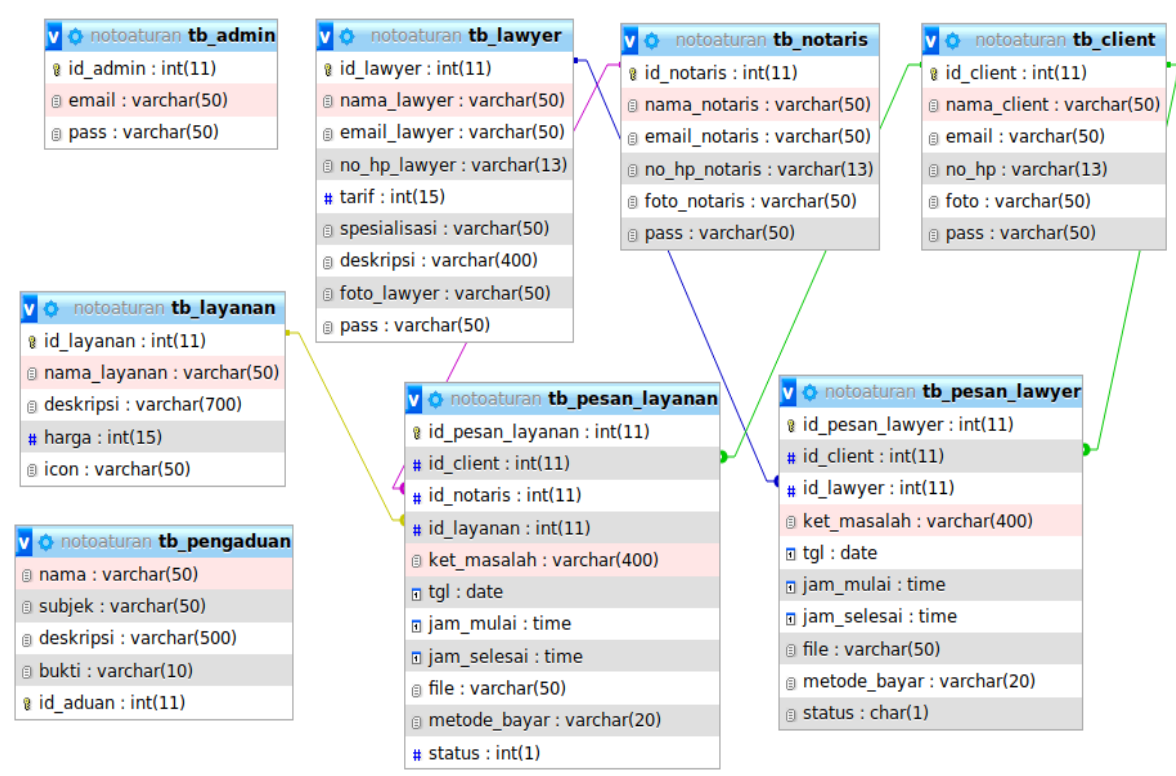

Fig 3. ER Diagram

\section{Implementation}

Implementation of coding is a process of translating the diagram into source code so that it becomes a usable website. The author uses the CodeIgniter 3 framework as the main framework of the website. The author uses the Visual studio code application to write code. The code file is divided into 3 main parts, namely Model, View, and Controller. A model is a folder or directory inside contains code related to the database. All functions like create, read, update, and delete databases are in the model section. The view is a folder that contains the code used to display the website to users. The view folder is the handle frontend. The controller is a folder that contains the code used to connect the functions of the model to be displayed to the section view.

\section{Testing}

Initial testing is carried out to test the overall functionality of the program. Researchers tested using three accounts consisting of client accounts, notary accounts, and admin accounts. The method used in the testing system is the black box testing method. Researchers tested the client functionality by registering, logging in, placing orders, and submitting complaints. On the side of notaries and lawyers, researchers conduct tests by testing the notary's functionality, where notaries can $\log$ in, view order data, and approve or reject incoming orders. Meanwhile, on the admin side, the researcher tested it by trying to do CRUD to all the tables displayed on the dashboard.

\section{Deployment}

Deployment is an activity that aims to distribute applications that have been worked on by developers to be available online on the internet. The deployment process is carried out after the testing phase is complete.

\section{Maintenance}

Operation and maintenance are the final stage in system development. From this result it is obtained to find out whether this application needs improvement including correction of errors, repair and implementation of system units and services.

\section{RESULT}

This research has produced a legal aid website called Notoaturan. Notoaturan website is a website that provides notary services and the search for Lawyers. Notoaturan website is divided into three main sections, namely the main website for clients, admin dashboard, and notaries and lawyer dashboard. On the main page for clients, the activities that can be carried out include login, registering, viewing a list of services, viewing a list of lawyers, as well as ordering services and ordering lawyers. Admin dashboard, the admin can perform several activities, namely viewing the list of clients, lawyers, notaries, and orders. Admin also has the right to create, delete and update the data contained in the database through the admin dashboard. In the dashboard of lawyers and notaries, you can see a list of orders that have been entered and can determine whether the lawyer and notary will take or reject the order.

On the home page for the client, there is a header that contains services that can be used by the client, namely the homepage, looking for lawyers, assistance, and complaints. 


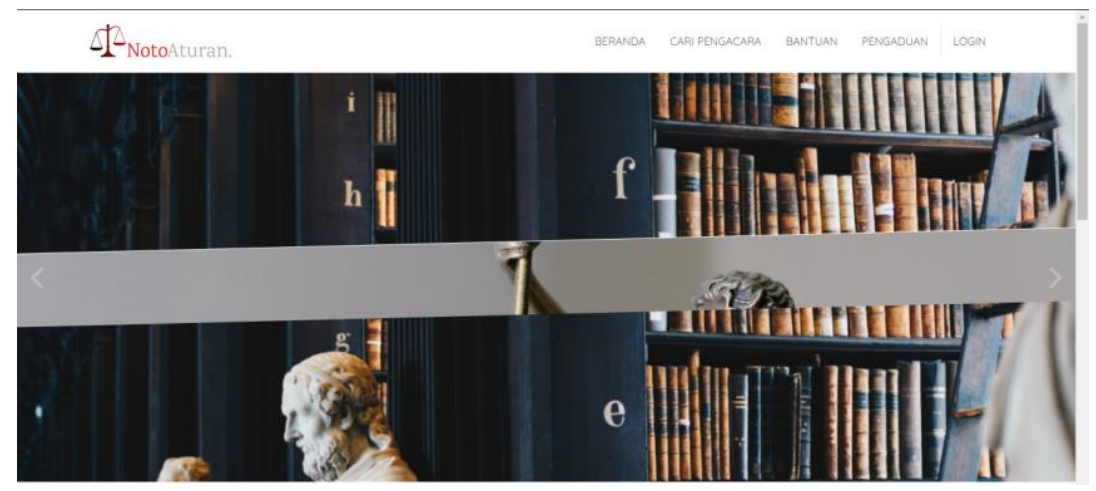

Fig 4. Website Header

There is also a list of notary services provided such as making business entities, copyrights, and so on. $\Delta t_{\text {Notosturan. }}$

Layanan Kami

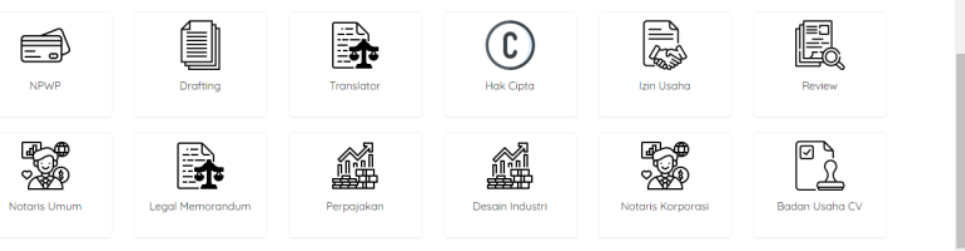

Fig 5. List of notary services

The list of services contained on the client's homepage is used to place an order for these services. If the client presses the icon of service, the client will be directed to the order page. The order page will display a brief description of the selected service and ask the client to fill in a description of the problem to be submitted.
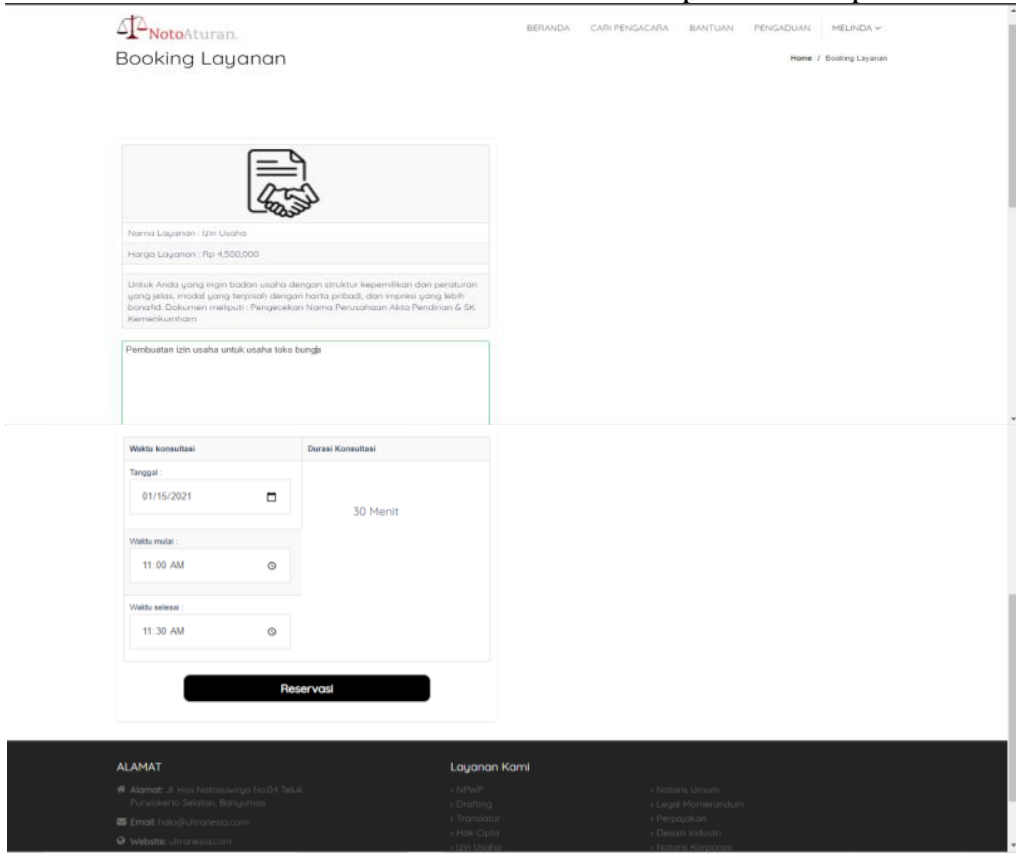

Fig 6. Order page

After placing an order, the client will be directed to make a checkout of the order. 


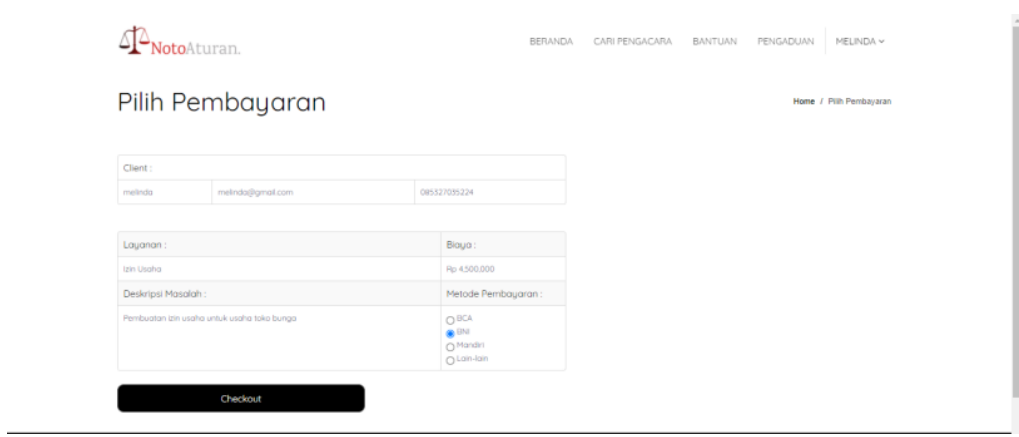

Fig 7. Checkout page

Then the client will be asked to upload proof of payment in the form of uploading proof of payment.

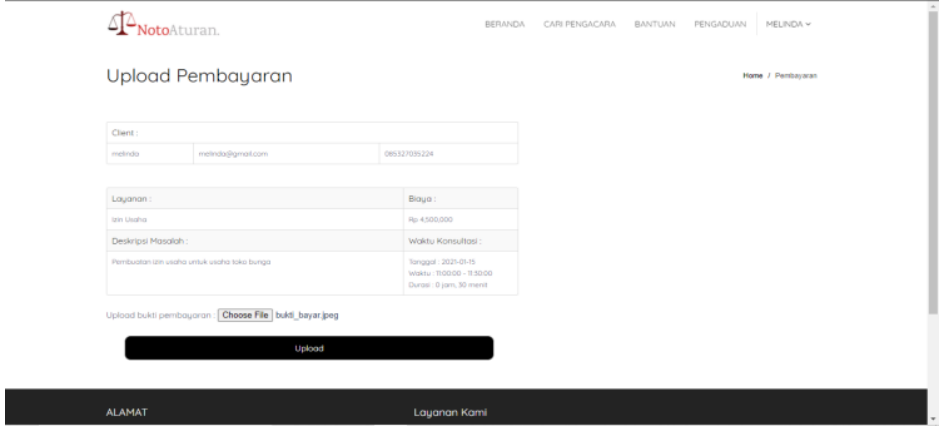

Fig 8. Proof of payment upload page

After the payment process is complete, the order will enter the order history with the order status still pending or waiting for approval from the notary or lawyer in charge.

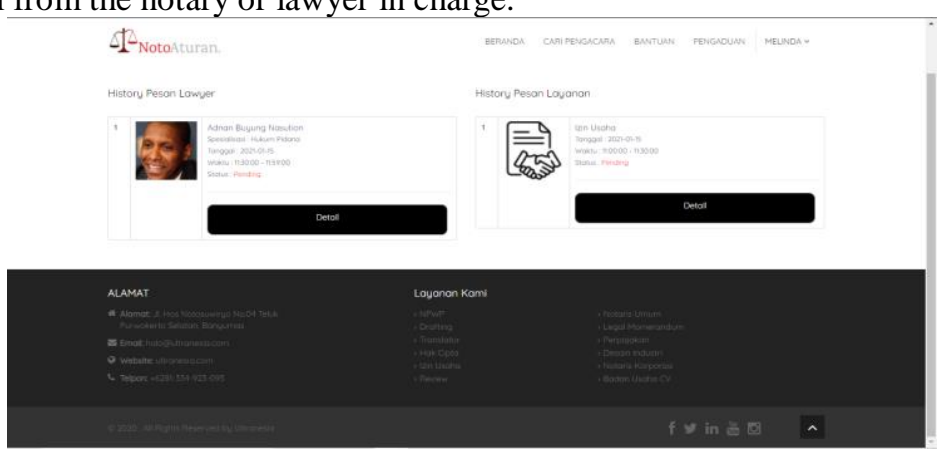

Fig 9. Order history page

The ordering process for lawyer and notary services has the same process. The client will choose a lawyer and provide a brief description of the problem. Then the client makes an order and makes a payment and then waits for the intended lawyer to approve the order or not. In addition to ordering lawyers and notary services, there are assistance services that clients can use to get information about procedures or articles about the services provided. These services are located on the "Bantuan" tab located in the header of the website.

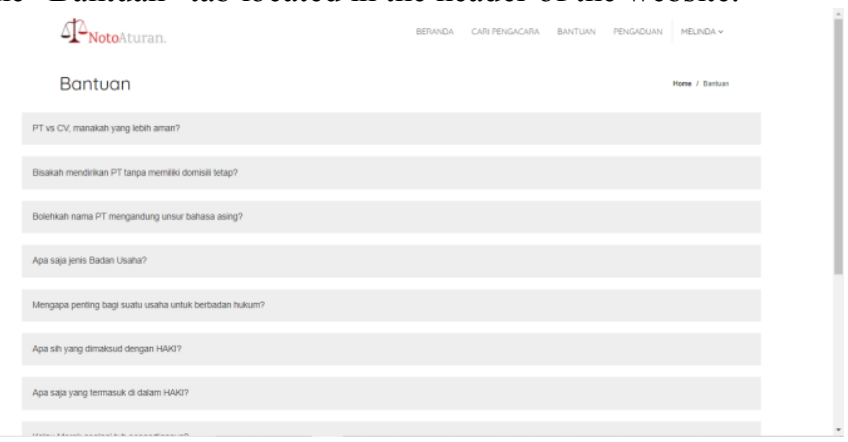

Fig 10. Bantuan page 
The last service that is available on the client page of the notification website is complaints. This complaint service can be used to make complaints if there is a violation in an area to be forwarded to the authorities in that area. Complaint services can be accessed through the complaints tab located in the header of the website.

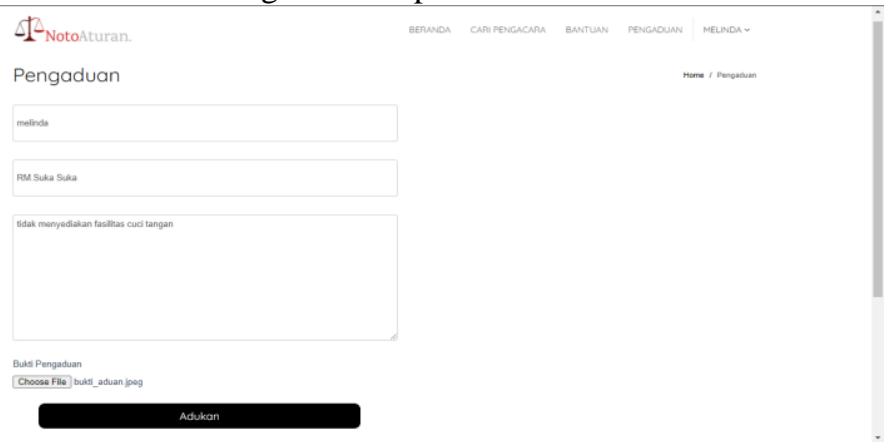

Fig 11. Pengaduan page

On the admin page, there are 4 menus, namely lawyer/advocate, notary, client, and booking. Admin can perform CRUD (create, read, update and delete) of all data in the admin dashboard.

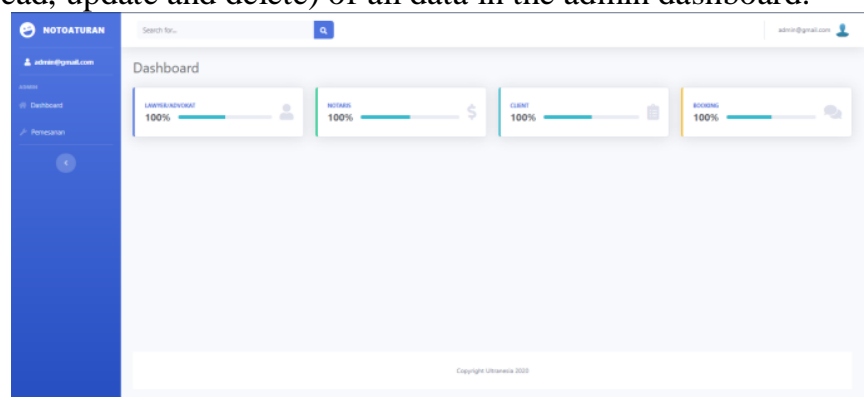

Fig 12. Admin Dashboard

On the dashboard page of lawyers and notaries, lawyers and notaries can see a list of orders that have been entered. Apart from looking at the list of orders that have come in, lawyers and notaries have the action to approve or reject incoming orders.
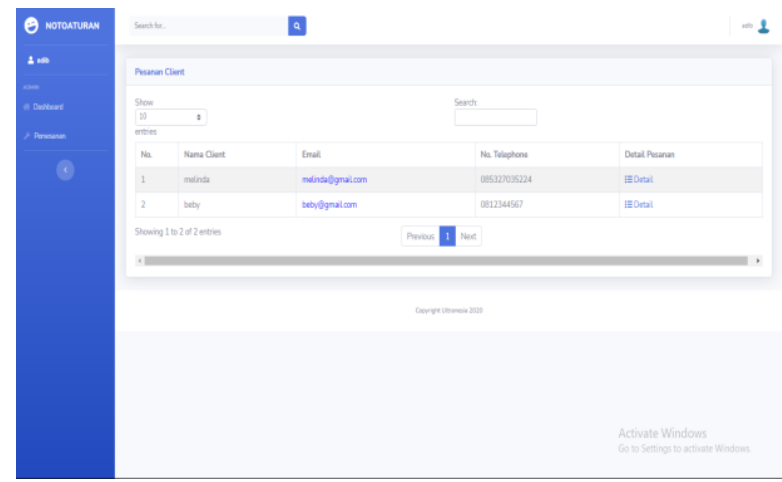

Fig 13. Notary dashboard

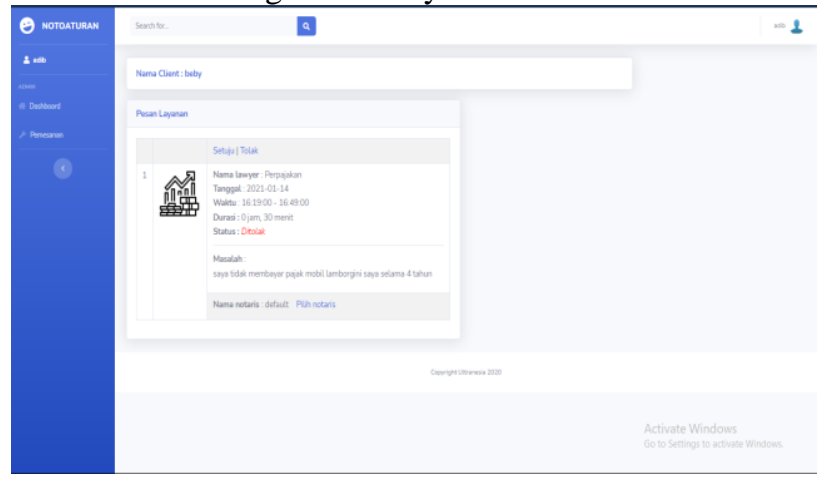

Fig 14. Lawyer Dashboard 
After all website services have been created, the next step is testing. The testing process uses the black-box testing method. The following results from the testing process are write down below.

Table 3

Results with The Black Box Testing Method

\begin{tabular}{lll}
\hline \multicolumn{1}{c}{ Name of Function } & \multicolumn{1}{c}{ activities } & Result \\
\hline Lebsite Header & displays the website header & Success \\
Order Page & Display list of notary services & Success \\
Checkout Page & Display data selected services & Success \\
& $\begin{array}{l}\text { Asking user to fill some data about the } \\
\text { problem }\end{array}$ & Success \\
$\begin{array}{l}\text { Proof of Payment Upload } \\
\text { Order History Page }\end{array}$ & Asking user to upload the proof of payment & Success \\
Help (Bantuan) Page & Display all the order history & Success \\
Complaint (Pengaduan) Page & $\begin{array}{l}\text { Display some question and answer about the } \\
\text { website and the services }\end{array}$ & Success \\
Admin Dashboard & Display all existing table & Success \\
Notary Dashboard & Display the incoming and history order & Success \\
Lawyer Dashboard & Display the incoming and history order & Success \\
\hline
\end{tabular}

\section{DISCUSSIONS}

The notoaturan website has 2 main services, namely to order notary services and order lawyers. There is an additional service in the form of help containing several questions and answers regarding some of the notary services provided. There is also a complaint service that can be used by the public to report a violation that has occurred in an area. Notoaturan website is divided into three main parts, the main website used by the client, the admin dashboard, and the notary and lawyer dashboard. The main website is used by clients to process transactions for notary services or lawyer orders.

Processes that can be carried out by the client on the website include login, order notary services, and order lawyers. Login is used as a client requirement to place orders for notary and lawyer services. Ordering for notary services is made by entering data such as a description of the problem, and consultation time. Clients are required to make an order payment in advance so that they can consult with a notary regarding the problem. lawyers ordering has the same process as ordering notary services. But the client can choose the lawyer he wants to order according to his wishes. Clients are required to make an order payment in advance so that they can carry out consultations regarding their problems. The client also has to wait whether the lawyer ordered gives approval or not.

Apart from the main website for clients, there is also a notary and lawyer dashboard. Some of the processes that can be carried out in the dashboard of notaries and lawyers, include viewing the list of incoming orders, with client details and consultation times submitted by the client, and approving or rejecting client orders.

Furthermore, there is the admin dashboard, the admin has access rights to all tables in the database. So, in the admin dashboard, several processes can be done, it is Create, Admin can add client users, notaries, and lawyers through the admin dashboard. Read, the admin dashboard displays all the data contained in the database in table form. The data includes data on clients, notaries, lawyers, orders for notary services, and orders for a lawyer. Update, admin can update data on notary and lawyer data and orders. Delete, the delete process is used to delete data from a table in the database.

\section{CONCLUSION}

Based on the analysis and discussion that has been presented, conclusions can be drawn are Notoaturan website is a website that provides notary services and searches for a lawyer. Notoaturan website provides a public 
complaint service if occurs an offense. Notoaturan websites provide time efficiency both from the client-side and in terms of notaries and lawyers in the consultation and service process. The use of the CodeIgniter 3 framework makes the file structure and code neat and structured. The black-box testing method shows that all the functions contained on the website are running well.

\section{REFERENCES}

Boni Garcia. 2017. "Mastering Software Testing with JUnit 5 Comprehensive Guide to Develop High-Quality Java Applications by Boni Garcia (z-Lib."

Christudas Binildas. 2019. "MySQL. In: Practical Microservices Architectural Patterns.” Pp. 877-84 in. Apress, Berkeley, CA.

Eka Wida Fridayanthie, Tias Mahdiati. 2016. "RANCANG BANGUN SISTEM INFORMASI PERMINTAAN ATK BERBASIS INTRANET (STUDI KASUS: KEJAKSAAN NEGERI RANGKASBITUNG)." JURNAL KHATULISTIWA INFORMATIKA IV(2):126-38.

Endra, Robby Yuli, Ahmad Cucus, and M. Aditya Wulandana S. 2020. "Perancangan Aplikasi Berbasis Web Pada System Aeroponik Untuk Monitoring Nutrisi Menggunakan Framework CodeIgniter.” 11(1):10-16.

Hendini, Ade. 2016. "PEMODELAN UML SISTEM INFORMASI MONITORING PENJUALAN DAN STOK BARANG (STUDI KASUS: DISTRO ZHEZHA PONTIANAK).” JURNAL KHATULISTIWA INFORMATIKA IV(2):107-16.

Knapp Jake, Zeratsky John, Kowitz Braden. 2016. Sprint: How to Solve Big Problems and Test New Ideas in Just Five Days. Google Ventures.

Ma'ruf, Luthfie Auditya Amarul, Condro Kartiko, and Wiguna Citra. 2020. "BLACK BOX TESTING BOUNDARY VALUE ANALYSIS PADA APLIKASI SUBMISSION SYSTEM.” Edik Informatika 6(2).

Manhas, Jatinder. 2017. "Initial Framework for Website Design and Development." International Journal of Information Technology. DOI: 10.1007/s41870-017-0045-4.

Ogala, E., and A. O. Sylvester. 2019. "CONCEPT OF WEB PROGRAMMING, AN OVERVIEW OF PHP VOL. $1 . " 1(12): 1-6$.

Putra. 2020. "Metode Pengembangan Perangkat Lunak (Waterfall, Rad, Agile, Prototype Dll)." Salamadian. Retrieved January 23, 2021 (https://salamadian.com/metode-pengembangan-perangkat-lunak/).

RI, UU. 2011. "Undang Undang No.16 Tahun 2011 Tentang Bantuan Hukum Bagi Masyarakat Kurang Mampu Untuk Menjamin Hak Konstitusi Warga Negara Bagi Keadilan Dan Kesetaraan Dimuka Hukum.”

Sudradjat, Adjat. 2019. "MVC Concept in the Development of Information System for Rental Office Utilities Cost." 4(1).

Suharsana, I. Ketut, I. G. P. Wirarama, Wedashwara Wirawan, Ni Luh, and Ayu Kartika. 2016. "Implementasi Model View Controller Dengan Framework CodeIgniter Pada E-Commerce Penjualan Kerajinan Bali." JURNAL SISTEM DAN INFORMATIK 11(1):19-28.

Tabrani Muhamad, and Pudjiarti Eni. 2017. "PENERAPAN METODE WATERFALL PADA SISTEM INFORMASI INVENTORI PT. PANGAN SEHAT SEJAHTERA.” Jurnal Inkofar 1(2):30-40.

Tristianto, Chrisantus. 2018. "PENGGUNAAN METODE WATERFALL UNTUK PENGEMBANGAN SISTEM MONITORING DAN." XII(01):8-22.

Wijaya, Khana, and Andi Christian. 2019. "Implementasi Metode Model View Controller (MVC) Dalam Rancang Bangun Website SMK Yayasan Bakti Prabumulih.” Paradigma - Jurnal Komputer Dan Informatika 21(1):95-102. doi: 10.31294/p.v21i1.5092. 